Creative commons User License: CC BY-NC-ND

Abstracted by: EBSCOhost, Electronic Journals Service (EJS),

Google Scholar, Directory of Open Access Journals (DOAJ),

Journal Seek, Scientific Commons,

Food and Agricultural Organization (FAO), CABI and Scopus
Journal of Agricultural Extension

Vol. 21 (2) June, 2017

ISSN(e): 24086851; ISSN(Print); 1119944X

http://journal.aesonnigeria.org

http://www.ajol.info/index.php/jae

Email: editorinchief@aesonnigeria.org

\title{
Use of Social Media by Agricultural Undergraduate Students in Selected Universities in Nigeria \\ https://dx.doi.org/10.4314/jae.v21i2.10
}

\section{Orifah, M. 0.}

Department of Agricultural Economics and Extension, Federal University Dutse, Dutse, Jigawa State, Nigeria

Email: martinsorifah@gmail.com, Phone: 08036976320

ljeoma, M. C.

Department of Agricultural Extension and Rural Development, University of Ibadan, Ibadan, Oyo State, Nigeria

Email: ijeomamessiahc@gmail.com, Phone: 08066327203

\section{Olajide, B. R.}

Department of Agricultural Extension and Rural Development, University of Ibadan, Ibadan, Oyo State, Nigeria

Email: r.olajide@gmail.com, Phone: 08034077794

Wigwe, C. C.

Department of Agricultural Economics and Extension, University of Port Harcourt, Rivers State, Nigeria

Email: chimkanmawigwe@gmail.com, Phone: 08036538387

\section{Abstract}

The study analysed the usage of social media sites by undergraduate agricultural students in selected Universities in Nigeria. Multi-stage sampling procedure was used to select 425 undergraduate agricultural students in Nigeria. Data were obtained with questionnaire and were presented using percentage, and mean. Results revealed that the majority $(57.1 \%)$ of the students were female with an average age of 24 years. The majority (83.5\%) also accessed one to two social media sites on daily basis, and the sites most visited by the students were WhatsApp (100.0\%), Facebook (97.8\%), Instagram (76.9\%) and Google+ (74.7\%). Results also revealed that the majority of the students visited social media sites to just connect with friends $(\bar{x}=3.68)$, get the latest information on global trend in governance $(\bar{x}=3.63)$, for educational research and collaborative purpose $(\bar{x}=3.57)$, and keep themselves occupied when bored $(\bar{x}=3.41)$. To inculcate in undergraduate agricultural students a sense of collaboration and networking needed in this era of interdisciplinary research, lecturers should further encourage the students to intensify on the use of social media sites for research purposes and to connect with other researchers rather than just connecting with friends.

Keywords: Social media, Agricultural Undergraduates, Nigeria 
Creative commons User License: CC BY-NC-ND

Abstracted by: EBSCOhost, Electronic Journals Service (EJS), Google Scholar, Directory of Open Access Journals (DOAJ), Journal Seek, Scientific Commons,

Food and Agricultural Organization (FAO), CABI and Scopus
Journal of Agricultural Extension

Vol. 21 (2) June, 2017

ISSN(e): 24086851; ISSN(Print); 1119944X

http://journal.aesonnigeria.org

http://www.ajol.info/index.php/jae

Email: editorinchief@aesonnigeria.org

\section{Introduction}

Social media refers to various forms of media content that are publicly available and created by end-users (Kaplan \& Haenlein, 2010). Social media is an online platform that focuses on building social relations among people, who share interests, ideas, information, background or activities (Anyanwu, Ossai-Onah, \& Iroeze, 2013). Kim, Sin and Yoo-Lee (2009) noted that social media is a form of electronic communication (as Web sites for social networking and micro-blogging) through which users create online communities to share information, ideas, personal messages, and other content (such as pictures, videos, voice notes etc). The term social media is also referred as social networking sites. In the views of Eke, Omekwu, and Odoh (2014), social networking sites are modern interactive communication channels through which people connect to one another, interact, share ideas, experiences, pictures, messages, information of interest and collaborate. Social media sites (such as WhatsApp, Skype, Facebook, Imo, Hangout, etc) can be used for online learning, collaborations, and conducting focus group discussion among very many uses.

The advent of social media and its growing popularity amongst students in everyday living has made it an important tool in education. According to Junco and Cole-Avent (2008), the intersection of social media and learning in higher education is an emerging field of study and its exploration is important because it will likely continue to be a meaningful component of students' lives, campus culture and the college experience. Rowlands, Nicholas, Russell, Canty, and Watkinson (2011) noted that social media have become important complementary channels for disseminating and discovering research.

Social networking sites have the capabilities of educating, informing, entertaining and inflaming the audience (Eke, Omekwu, \& Odoh, 2014). Social media is a widespread tool for communication and exchange of ideas. It facilitates the reach of vast audience that could hitherto not be reached by traditional media and has emerged as the new way in which people connect socially, by integrating information and communication technologies (such as mobile and web-based technologies), social interaction, and the construction of words, pictures, videos and audio formats (Zeng \& Gerritsen, 2014). However, it is worthy of note that the use of social media amongst users vary with content and personality. Whereas, some people use social media sites as a time killer to get out of boredom, connect with friends, post new pictures, videos, etc., others use it not just as a connect to meet people and interact, but to also collaborate and meet in a constructive manner.

There is no doubt that social media has become an integral part of students' life as several studies (Junco \& Cole-Avent, 2008; Anyanwu, Ossai-Onah, \& Iroeze, 2013; Eke, Omekwu, \& Odoh, 2014; Yuhas \& BrckaLorenz, 2015) have confirmed. However, the extent and purpose of use of social media by agricultural undergraduates in Nigerian universities have not been ascertained. Given the relevance social media could serve even in the research endeavours of the targets of this study, how efficiently and effectively they have deployed the various opportunities of social media becomes imperative. 
Creative commons User License: CC BY-NC-ND

Abstracted by: EBSCOhost, Electronic Journals Service (EJS),

Google Scholar, Directory of Open Access Journals (DOAJ),

Journal Seek, Scientific Commons,

Food and Agricultural Organization (FAO), CABI and Scopus
Journal of Agricultural Extension

Vol. 21 (2) June, 2017

ISSN(e): 24086851; ISSN(Print); 1119944X

http://journal.aesonnigeria.org

http://www.ajol.info/index.php/jae

Email: editorinchief@aesonnigeria.org

Given the forgoing, the study examined the use of social media by agricultural undergraduate students in Nigeria. Specifically, the study:

i. described the socio-demographic characteristics of the respondents;

ii. identified the types of social media sites respondents use;

iii. ascertained the extent of social media usage by the respondents; and

iv. ascertained the purpose of social media usage by the respondents.

\section{Methodology}

The population for the study comprised all undergraduate agricultural students in the selected universities in Nigeria. Data were collected with the aid of structured questionnaire. Multistage sampling procedure was adopted to select the respondents for the study. First, three geopolitical zone (South-West, South-South and NorthWest) were randomly selected. The second stage involved the random selection of one state from each of the geopolitical zone selected (and this gave rise to Rivers State from South-South; Osun State from South-West; and Jigawa State from NorthWest). Thirdly, from each of the states selected, one university was randomly selected: Rivers State University of Science and Technology for Rivers State; Federal University Dutse for Jigawa State and Obafemi Awolowo University for Osun state. From each of the schools selected, 150 questionnaires were administered to undergraduate agricultural students, making a total of 450 respondents. However, of the 450 questionnaire, only 425 were valid for analysis. Data were analysed using percentage and mean.

\section{Results and Discussion}

\section{Socio-Demographic Characteristics}

Table 1 reveals that the majority of the respondents were female $(57.1 \%)$. This implies that there were more female agricultural undergraduates in Nigerian universities than male. The Table also shows that the majority of the respondents were single $(85.7 \%)$, between 23 - 28 years $(56.0 \%)$ of age with a mean age of $24 y e a r s$, and visited social media sites on daily basis (83.5\%). Data obtained for sex and age of the respondents are expected as most Nigeria's undergraduates expectedly are mostly unmarried or yet to be engaged with age range between 18 and 30 years. Beyond age 30, they are not expected to participate in the mandatory one-year national service. Also, data on daily visits to social media sites presents the picture of what obtains for most youths and adults alike in Nigeria in the most recent times, especially with access to Internet facilities even in the remotest part of the country (Amusat \& Olajide, 2013). All the respondents $(100.0 \%)$ accessed one or two social media groups. This implies that social media is an integral part in the lives of the students as they are all acquainted with social networking sites and hence, should be explored as an avenue to communicate, interact and collaborate with them. This supports the notion of Junco and Cole-Avent (2008), that social media has become a meaningful component of students' lives, campus culture, and the college experience. It also supports the findings of Hadebe, Owolabi, and Mlambo 
Creative commons User License: CC BY-NC-ND

Abstracted by: EBSCOhost, Electronic Journals Service (EJS),

Google Scholar, Directory of Open Access Journals (DOAJ),

Journal Seek, Scientific Commons,

Food and Agricultural Organization (FAO), CABI and Scopus
Journal of Agricultural Extension

Vol. 21 (2) June, 2017

ISSN(e): 24086851; ISSN(Print); 1119944X

http://journal.aesonnigeria.org

http://www.ajol.info/index.php/iae

Email: editorinchief@aesonnigeria.org

(2016) and Knight-McCord et al (2016) that undergraduate students use social networking sites on daily basis.

Table 1: Distribution of respondents by their socio-demographic characteristics

\begin{tabular}{lll}
\hline Variable & Percentage $(\mathbf{n}=\mathbf{4 2 5})$ & Mean \\
\hline Sex & 42.9 \\
Male & 57.1 \\
Female & \\
Age & 36.3 \\
$17-22$ & 56.0 \\
$23-28$ & 7.7 & 23.7 \\
$29-34$ & \\
Membership of a social & \\
media group & 100.0 \\
Yes & 0.0 \\
No & \\
Marital Status & 85.7 \\
Single & 14.3 \\
Married & \\
Frequency of use of & \\
social media & 83.5 \\
Daily & 9.9 \\
Two days interval & 3.3 \\
Three days interval & 3.3 \\
Once a week & 0.0 \\
Once monthly & 0.0 \\
Yearly & \\
Source: Field survey, 2016 &
\end{tabular}

\section{Types of Social Media Sites Visited}

Table 2 shows that respondents visited WhatsApp chat (100.0\%), Facebook (97.8\%), Instagram (76.9\%), Twitter (75.8\%), Yahoo messenger (75.8\%) and Google+ $(74.7 \%)$. Other social media sites most visited by the respondents were BBM (73.6\%), YouTube (71.4\%), Imo (62.6\%) and Skype (57.1\%). The result further shows low usage of Netlog (18.7\%), Flickr (26.4\%), Myspace (27.5\%) and Linkedln $(27.5 \%)$ by the respondents. Low patronage of site like Lnkedln suggests that students hardly patronise professional and academic based media. With $100.0 \%$ of the students visiting WhatsApp, it implies that all the students were familiar with and visit WhatsApp social networking site and hence should be explored as an avenue by lecturers, research institutes to reach out to the students. This finding 
Creative commons User License: CC BY-NC-ND

Abstracted by: EBSCOhost, Electronic Journals Service (EJS),

Google Scholar, Directory of Open Access Journals (DOAJ),

Journal Seek, Scientific Commons,

Food and Agricultural Organization (FAO), CABI and Scopus
Journal of Agricultural Extension

Vol. 21 (2) June, 2017

ISSN(e): 24086851; ISSN(Print); 1119944X

http://journal.aesonnigeria.org

http://www.ajol.info/index.php/jae

Email: editorinchief@aesonnigeria.org

corroborates with the findings of Eke, Omekwu, and Odoh (2014), that Facebook, Yahoo, 2go, Google+, YouTube, and WhatsApp as the most visited social media

sites by undergraduate university students. This also validates the findings of Knight-McCord, et al (2016) who identified that college students use Instagram, Snapchat, Facebook, twitter and YouTube. All the identified social media sites visited as reported in this study lend credence to the fact that most universities and college students are more hooked to entertainment and showbiz related sites as they catch up with latest and trending issues relating to sports and entertainment. It is no longer strange that this segment of Nigeria's population craves more for possible career pursuits in music and acting than academics; the purpose of which they are in school. Subscription of this population to social media sites like 2 go and WhatsApp chat can also be explained along the line of the need to be in touch with friends and relatives as well as being member of several groups on these sites. Contrastingly, low patronage of sites like Netlog, Flickr, and Myspace could be as a result of seeming unpopularity of these media due to perhaps the fact that these media possess less advantage in term of the features and services they offer. They may also be difficult or unfriendly to navigate.

Table 2: Distribution of respondents by types of social media sites visited

\begin{tabular}{ll}
\hline Social media site visited & Percentage \\
\hline WhatsApp & 100.0 \\
Facebook & 97.8 \\
Instagram & 76.9 \\
Twitter & 75.8 \\
Yahoo messenger & 75.8 \\
Google+ & 74.7 \\
BBM & 73.6 \\
YouTube & 71.4 \\
Imo & 62.6 \\
Skype & 57.1 \\
2go & 52.7 \\
Nairaland & 48.4 \\
Blogs & 45.1 \\
Badoo & 44.0 \\
WeChat & 40.7 \\
Hangout & 28.6 \\
Linkedln & 27.5 \\
Myspace & 27.5 \\
Flickr & 26.4 \\
Netlog & 18.7 \\
\hline
\end{tabular}

${ }^{\star}$ Multiple responses. Source: Field survey, 2016 
Creative commons User License: CC BY-NC-ND

Abstracted by: EBSCOhost, Electronic Journals Service (EJS),

Google Scholar, Directory of Open Access Journals (DOAJ),

Journal Seek, Scientific Commons,

Food and Agricultural Organization (FAO), CABI and Scopus

\section{Extent of Social Media Usage}

Table 3, shows high usage of WhatsApp $(\bar{x}=2.96)$, Facebook $(\bar{x}=2.80)$, Instagram $(\bar{x}=2.24)$, Google $+(\bar{x}=2.20)$, Twitter $(\bar{x}=2.15)$, Yahoo messenger $(\bar{x}=2.11)$, amongst the respondents. The plethora of these sites as listed for high usage presents similar picture as found in sites visited earlier reported in this study. It simply implies that the more patronage in terms of visitation, the more the profile of these sites in terms of use by the respondents. The result on the extent of usage is in consonance with the findings of Marisol, Sergio and Pedro (2012) who also reported high usage of Facebook social media network among students and researchers, as these sites support information sharing, group work, research collaboration, networking, amongst others. It also corroborates with the findings of Eke, Omekwu, and Odoh (2014), who reported high usage of Facebook, Google+, WhatsApp and YouTube social media sites amongst undergraduate students.

Table 3: Extent of social media usage by respondents

\begin{tabular}{ll}
\hline Social media site visited & Mean \\
\hline WhatsApp & $2.96^{*}$ \\
Facebook & $2.80^{*}$ \\
Instagram & $2.24^{*}$ \\
Google+ & $2.20^{*}$ \\
Twitter & $2.15^{*}$ \\
Yahoo messenger & $2.11^{*}$ \\
BBM & $2.08^{*}$ \\
YouTube & $2.00^{*}$ \\
Imo & 1.89 \\
Nairaland & 1.77 \\
Skype & 1.69 \\
2go & 1.62 \\
Blogs & 1.59 \\
WeChat & 1.50 \\
Badoo & 1.50 \\
Hangout & 1.37 \\
Linkedln & 1.36 \\
Myspace & 1.33 \\
Flickr & 1.30 \\
Netlog & 1.22 \\
\hline
\end{tabular}

${ }^{*}$ High. Source: Field Survey, 2016

The use of social media sites such as Netlog $(\bar{x}=1.22)$, Linkedln $(\bar{x}=1.36)$, Blogs $(\bar{x}$ $=1.59)$, Myspace $(\bar{x}=1.33)$, WeChat $(\bar{x}=1.50)$, Skype $(\bar{x}=1.69)$, Imo $(\bar{x}=1.89)$ that support learning, research and collaborative purposes was low amongst respondents. This could be as a result of the relative unpopularity of these social 
Creative commons User License: CC BY-NC-ND

Abstracted by: EBSCOhost, Electronic Journals Service (EJS),

Google Scholar, Directory of Open Access Journals (DOAJ),

Journal Seek, Scientific Commons,

Food and Agricultural Organization (FAO), CABI and Scopus

\author{
Journal of Agricultural Extension \\ Vol. 21 (2) June, 2017 \\ ISSN(e): 24086851; ISSN(Print); 1119944X \\ http://journal.aesonnigeria.org \\ http://www.ajol.info/index.php/iae \\ Email: editorinchief@aesonnigeria.org
}

media sites amongst undergraduate agricultural students in Nigerian universities. This result supports with the findings of Eke, Omekwu, and Odoh (2014), which reported low extent of usage of Linkedln, Myspace, 2go, Badoo, amongst other social media sites by undergraduate university students. Hence, it is imperative that agricultural students be exposed to the importance and usefulness of these social media sites.

\section{Purpose of Social Media Usage}

Table 4 shows that respondents used social media sites to connect with friends $(\bar{x}=$ 3.68), get the latest information on global trend in governance $(\bar{x}=3.63)$, for educational research and collaborative purpose $(\bar{x}=3.57)$, and keep themselves occupied when bored $(\bar{x}=3.41)$. However, there was low usage of social media sites for product marketing by the respondents $(\bar{x}=2.27)$. This implies that undergraduate agricultural students use social media sites to connect, interact, and share with friends; and also for research and collaborative purposes such as online learning, group formation and discussion. This corroborates the findings of Eke, Omekwu, and Odoh (2014) who found that undergraduates use social media sites for communicating and interacting with friends, for online learning, and for academic purposes such as group discussion, and getting study partners online. It also supports the findings of Kim, Sin and Yoo-Lee (2009) that undergraduates use social networking sites for information sourcing, keeping in touch with others, get updates/news, be aware of popular trends and glean the opinions of others. 
Creative commons User License: CC BY-NC-ND

Abstracted by: EBSCOhost, Electronic Journals Service (EJS), Google Scholar, Directory of Open Access Journals (DOAJ), Journal Seek, Scientific Commons,

Food and Agricultural Organization (FAO), CABI and Scopus
Journal of Agricultural Extension

Vol. 21 (2) June, 2017

ISSN(e): 24086851; ISSN(Print); 1119944X

http://journal.aesonnigeria.org

http://www.ajol.info/index.php/jae

Email: editorinchief@aesonnigeria.org

Table 4: Purpose of social media use by respondents

\begin{tabular}{|c|c|}
\hline Purpose of use & Mean \\
\hline I use social media sites to connect with friends & $3.68^{*}$ \\
\hline $\begin{array}{l}\text { I visit social media sites to get the latest information on global } \\
\text { trend in governance }\end{array}$ & $3.63^{*}$ \\
\hline $\begin{array}{l}\text { I use social media site for educational research and } \\
\text { collaborative purpose }\end{array}$ & $3.57^{*}$ \\
\hline $\begin{array}{l}\text { I use social media sites to keep myself occupied when I am } \\
\text { bored }\end{array}$ & $3.41^{*}$ \\
\hline I use social media sites to get the latest gist in town & $3.33^{*}$ \\
\hline I use social media sites to entertain myself & $3.29^{*}$ \\
\hline $\begin{array}{l}\text { I use social media sites for academic purposes such as group } \\
\text { discussion, and getting study partners online }\end{array}$ & $3.19^{*}$ \\
\hline I use social media sites to reach out to more people & $3.13^{*}$ \\
\hline I use social media sites for online learning & $3.09^{*}$ \\
\hline I use social media sites for mobilization purpose & $2.66^{*}$ \\
\hline I use social media sites to market my products & 2.27 \\
\hline
\end{tabular}

Table 4 shows that undergraduate agricultural students of Nigerian universities use social media sites to connect and interact with friends, get latest information on global trend and for educational and collaborative purposes. Anyanwu, Ossai-Onah, and Iroeze (2013) had reported that undergraduate students use social media sites just for the purpose of socialization only and that they use it in deterrent to their academics, as it is assumed that they spend more time on social media just socializing than with their books.

\section{Conclusion and Recommendations}

Agricultural undergraduates utilise one or two social media sites, with a majority of the respondents making use of social media sites on daily basis. The sites mostly used by the respondents were WhatsApp, Facebook, Instagram and Google+. Findings also show that the respondents use social media sites to connect with friends, get the latest information on global trend in governance, for educational research and collaborative purpose, keep themselves occupied when bored, and get the latest gist in town. Undergraduate agricultural students should further be encouraged by lecturers to make use of social media sites for research purposes and to connect with other researchers rather than just connecting with friends

Lecturers should encourage the students to work in groups using social media sites by giving them group tasks that require them collaborating online. 
Creative commons User License: CC BY-NC-ND

Abstracted by: EBSCOhost, Electronic Journals Service (EJS),

Google Scholar, Directory of Open Access Journals (DOAJ),

Journal Seek, Scientific Commons,

Food and Agricultural Organization (FAO), CABI and Scopus
Journal of Agricultural Extension

Vol. 21 (2) June, 2017

ISSN(e): 24086851; ISSN(Print); 1119944X

http://journal.aesonnigeria.org

http://www.ajol.info/index.php/jae

Email: editorinchief@aesonnigeria.org

\section{Reference}

Amusat A. S and Olajide B. R. (2013). Availability and use of information communication technologies (ICTs) for technology dissemination by national agricultural research institutes in Southwestern Nigeria. Journal of Agricultural Management and Rural Development, 4(1), 187-194

Anyanwu, E. U., Ossai-Onah, V. O., \& Iroeze, P. (2013). Use of social media tools among Nigerian undergraduates in three selected tertiary institutions in Imo State, Nigeria. Journal of Information and Knowledge Management, 4(2), 4652.

Eke, H. N., Omekwu, C. O., \& Odoh, J. N. (2014). The use of social networking sites among the undergraduate students of University of Nigeria, Nsukka. Library Philosophy and Practice. http://digitalcommons.unl.edu/libphilprac/1195 Hadebe, Z., Owolabi, Y., \& Mlambo, E. (2016). Use of social networking sites by undergraduate students in two African universities. Qualitative and Quantitative Methods in Libraries, 5, 743-749

Junco, R., \& Cole-Avent, G. A. (2008). An introduction to technologies commonly used by college students. New Directions for Student Services, 124, 3-17. Kaplan, A. M., \& Haenlein, M. (2010). Users of the world, unite: The challenges and opportunities of social media. Business Horizons, 53, 59-68.

Kim, K., Sin, S. J., \& Yoo-Lee, E. Y. (2014). Undergraduates' use of social media as information sources. College and Research Libraries, 442-457.

Knight-McCord, J., Cleary, D., Grant, N., Herron, A., Lacey, T., Livingston, T., \&

Emanuel, R. (2016). What social media sites do college students use most?. Journal of Undergraduate Ethnic Minority Psycholoy, 2,21.

Marisol, G. A., Sergio, R., \& Pedro, F. B. (2012). The academic use of social networks among university students. Scientific Journal of Media Education, 131-138, http://dx.doi.org/10.3916/C38-2012-03-04

Rowlands, I., Nicholas, D., Russell, B., Canty, N., \& Watkinson, A. (2011). Social media use in the research workflow. Learned Publishing, 24(3), 183-195.

Zeng, B., \& Gerritsen, R. (2014). What we do about social media in tourism? A review. Tourism Management Perspective, 10, 27-36. 